\title{
MOKELIS FOR KIDS MODUL EDUKASI LISTRIK SEBAGAI MEDIA PEMBELAJARAN KESELAMATAN LISTRIK ANAK USIA DINI
}

\author{
Gito Syahril Fajar ${ }^{1}$, Rahmad Prasetyo ${ }^{2}$, Dimas Mahendra ${ }^{3}$, Sigit Yatmono ${ }^{4}$ \\ ${ }^{1,2,3}$ Mahasiswa Jurusan Pendidikan Teknik Elektro FT UNY, ${ }^{4}$ Dosen Pendidikan Teknik Elektro FT UNY \\ Email: gitosfh@gmail.com
}

ABSTRACT

\begin{abstract}
This research aims to: (1) produce the design of Mokelis for Kids innovation of microcontroller-based electricity education module, (2) find out the performance and workings of Mokelis for Kids innovation of microcontroller-based electricity education, (3) know the advantages and benefits of Mokelis for Kids innovation of microcontroller-based electricity education module as an early childhood electrical safety learning media. The method used in this study is Research and Development $(R \& D)$ with the ADDIE development model according to Robert Maribe Branch or developing a microcontroller-based electricity education module that can provide electric shock simulations and play sound notifications in the form of warning of hazardous or safe conditions. The data obtained is the feasibility of learning media. The results showed that the performance of Mokelis for Kids was very good. Mokelis for kids learning media is in the feasible category with a score of 70.5 with a percentage of $80.11 \%$.
\end{abstract}

Keywords: learning media, electricity education, electricity safety

\begin{abstract}
ABSTRAK
Penelitian ini bertujuan untuk: (1) menghasilkan rancangan Mokelis for Kids inovasi modul edukasi listrik berbasis mikrokontroler sebagai media pembelajaran keselamatan listrik anak usia dini, (2) mengetahui kinerja dan cara kerja Mokelis For inovasi modul edukasi listrik berbasis mikrokontroler sebagai media pembelajaran keselamatan listrik anak usia dini, (3) mengetahui keunggulan dan manfaat Mokelis For Kids inovasi modul edukasi listrik berbasis mikrokontroler sebagai media pembelajaran keselamatan listrik anak usia dini. Metode yang digunakan dalam penelitian ini adalah Research and Development $(R \& D)$ dengan model pengembangan ADDIE menurut Robert Maribe Branch atau mengembangkan modul edukasi listrik berbasis mikrokontroler yang dapat memberikan simulasi kejut listrik dan memutar notifikasi suara berupa peringatan kondisi bahaya atau aman. Data yang diperoleh merupakan kelayakan media pembelajaran. Hasil Penelitian menunjukkan unjuk kerja Mokelis For Kids sangat baik. Media pembelajaran Mokelis For Kids masuk kategori layak dengan perolehan skor 70,5 dengan persentase 80,11\%.
\end{abstract}

Kata kunci: media pembelajaran, edukasi listrik, keselamatan listrik

\section{PENDAHULUAN}

Listrik dan peralatan kelistrikan merupakan sebuah bagian dari kehidupan manusia di masa kini, dengan berbagai fungsi dan kegunaannya dalam menunjang berbagai kebutuhan. Namun, di sisi lain peralatan kelistrikan memiliki risiko bahaya yang mengancam keselamatan diri. Penggunaan peralatan kelistrikan yang tidak sesuai standar baik dari segi pemasangan maupun material, akan meningkatkan risiko bahaya keselamatan.
Standar pemasangan peralatan kelistrikan telah diatur dalam Standar Nasional Indonesia (SNI) Persyaratan Umum Instalasi Listrik (PUIL) 2011 sebagai upaya pemerintah untuk mencegah terjadinya kecelakaan yang diakibatkan oleh gangguan-gangguan listrik. Namun pemasangan peralatan kelistrikan yang tidak sesuai standar pada PUIL 2011 dan kelalaian pengguna sering kali menyebabkan gangguan-gangguan yang membahayakan terutama terjadinya kejut listrik atau lebih sering dikenal oleh 
masyarakat awam dengan sebutan kesetrum.

Berdasarkan data statistik lembaga Electrical Safety Foundation International (ESFI) dari tahun 2015 hingga tahun 2016 kecelakaan fatal akibat kecelakaan yang disebabkan oleh listrik mengalami kenaikan sebesar 15\% yakni menjadi sejumlah 154 kecelakaan fatal, sedangkan kecelakaan ringan akibat listrik terjadi sebanyak 420 kali. Data tersebut diambil oleh ESFI dari U.S. Bureau of Labor Statistics. Angka tersebut menunjukkan bahwa kurangnya pengetahuan tentang keselamatan listrik yang terjadi pada masyarakat internasional.

Demikian juga di Indonesia, kecelakaan akibat listrik banyak ditemui di masyarakat, baik kecelakaan kecil maupun kecelakaan fatal yang dapat menyebabkan kematian. Salah satu artikel di laman surabaya.tibunnews.com pada tanggal 5 September 2018 mengabarkan bahwa terjadi kecelakaan akibat sengatan listrik dari listrik rumah yang mengakibatkan anak berusia 8 tahun meninggal dunia. Kecelakaan tersebut disebabkan karena 2 hal, yaitu pemasangan kabel listrik yang tidak sesuai standar dan ketidak tahuan anak mengenai bahaya memegang penghantar listrik yang tidak terisolasi. Selain itu pada laman portal berita beritaoposisi.com pada tanggal 31 Maret 2018, dikabarkan seorang anak meninggal disebabkan oleh kejut listrik karena anak tersebut berpegangan pada kabel PLN yang tidak terisolasi. Kecelakaan-kecelakaan kecil akibat sengatan listrik juga dapat menimbulkan trauma psikis pada anak, sehingga anak akan mengalami rasa takut untuk berhubungan dengan peralatan listrik hingga dewasa.

Berdasarkan permasalahan tersebut, perlunya sebuah teknologi yang mampu membantu meningkatkan pemahaman akan bahaya kelistrikan bagi anak-anak usia dini. Inovasi teknologi yang kita hadirkan berupa MOKELIS FOR KIDS Modul Edukasi Listrik Berbasis Mikrokontroler Sebagai Media Pembelajaran Keselamatan Listrik Anak Usia Dini yang dapat memberikan simulasi tentang bahaya peralatan Listrik dalam suatu modul interaktif. MOKELIS FOR KIDS menghadirkan sebuah inovasi trainer dengan simulasi-simulasi kecelakaan sederhana menggunakan sensor sentuh, vibrator dan modul MP3 untuk menampilkan efek suara.

Sensor sentuh pada rangkaian ini digunakan untuk simulasi sentuhan terhadap bahan konduktor listrik yang terbuka seperti kabel yang mengelupas dan kotak kontak yang terbuka. Vibrator akan digunakan sebagai simulasi kejut listrik yang terjadi akibat menyentuh sensor sentuh yang terdapat di modul MOKELIS FOR KIDS. Ketika sensor sentuh mendeteksi sentuhan, maka vibrator akan bergetar dan modul MP3 akan memutar suara notifikasi peringatan dan himbauan.

Menurut Kamus Besar Bahasa Indonesia (KBBI) Listrik adalah daya atau kekuatan yang ditimbulkan oleh adanya pergesekan atau melalui proses kimia, dapat digunakan untuk menghasilkan panas atau cahaya, atau untuk menjalankan mesin. Kebutuhan manusia akan energi listrik terus meningkat dari waktu kewaktu. Hal ini menunjukkan bahwa begitu tingginya manfaat listrik bagi kehidupan manusia. Disisi lain hal yang sering terlupakan adalah tentang bahaya yang dapat ditimbulkan oleh listrik. Padahal dari faktafakta yang kita jumpai, disamping manfaatnya yang begitu banyak ternyata listrik juga dapat menimbulkan bahaya. Secara umum bahaya listrik adalah sesuatu 
yang dapat mendatangkan (menimbulkan) kecelakaan, bencana, kerugian dan sejenisnya yang diakibatkan oleh adanya arus listrik. Selain karena Unsafe Condition, bahaya listrik juga bisa timbul karena adanya Unsafe Action, yang salah satunya adalah ketidaktaatan ataupun kelalaian dari manusia yang menggunakan energi listrik. Contoh bahaya yang mungkin dapat ditimbulkan oleh energi listrik terhadap manusia yaitu diantaranya kejutan, pingsan, luka bakar hingga kematian. Selain itu apabila terjadi hubung singkat pada instalasi/peralatan listrik, maka dapat menimbulkan kebakaran.

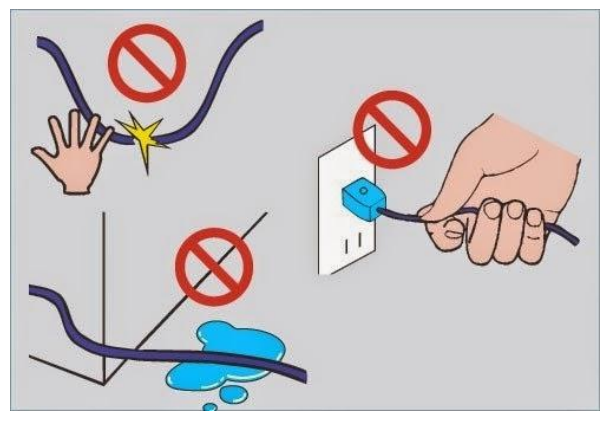

Gambar 1. Contoh bahaya dalam penggunaan kabel listrik

Arduino merupakan platform yang terdiri dari software dan hardware. Hardware Arduino sama dengan mikrokontroler pada umumnya, perbedaannya pada arduino ditambahkan penamaan pin agar mudah digunakan. Software Arduino bersifat open source sehingga dapat diunduh gratis di laman resmi arduino. Software ini digunakan untuk membuat dan memasukkan program ke dalam Arduino (Arifin dkk, 2016). Arduino Mega 2560 merupakan papan mikrokontroler berbasis ATMEGA 256 yang diproduksi oleh Atmel yang memiliki flash memori sebesar $256 \mathrm{~KB}$ sehingga memungkinkan untuk dimasuki program yang panjang. Arduino Mega 2560 memiliki 54 pin input/output digital, 16 pin input analog, dan 4 pin UARTs (hardware serial ports) sehingga dapat digunakan untuk aplikasi sistem dengan kebutuhan I/O yang banyak.

Sensor sentuh merupakan sensor yang digunakan untuk mendeteksi sentuhan tangan manusia. Parameter sentuhan bagi sensor sentuh dapat berupa suhu, kelembaban, tekanan dan tekstur. Menurut Setiaji (2010) Rangkaian sensor sentuh teridiri dari beberapa komponen meliputi resistor, transistor, optokopler, kapasitor, dioda dan relai. Sensor sentuh merupakan sensor yang umum digunakan sebagai tombol kapasitif suatu alat elektronik seperti telepon genggam, printer, dan monitor.

Mendeteksi jarak dapat dilakukan menggunakan rangkaian elektronik dengan bantuan cahaya ataupun gelombang suara. Gelombang suara yang dapat digunakan untuk mengukur jarak tertentu yakni gelombang ultrasonik. Besaran jarak yang dapat diukur oleh sensor ultrasonik berkisr antara 3cm hingga 3m (Pratama dkk, 2012). Sensor ultrasonik merupakan pendeteksi jarak yang memanfaatkan gelombang ultrasonik. Sensor ultrasonik biasanya berbentuk papan yang terdapat 2 buah tranduser didalamnya. Kedua tranduser tersebut salah satunya berfungsi sebagai transmitter (pemancar) dan salah satunya lagi berfungsi sebagai receiver (penerima) (Hernanto, 2014).

Vibrator merupakan motor listrik berukuran kecil didalamnya terdapat bandul yang tidak seimbang, ketika bandul berputar dengan cepat, maka akan menghasilkan getaran lembut yang akan terasa oleh manusia (Hernanto, 2014). Vibrator beroperasi pada tegangan 35VDC. Vibrator merupakan perangkat yang umum digunakan dalam telepon genggam 
sebagai notifikasi getar yang biasanya dimunculkan dalam mode hening.

Modul MP3 sistem digunakan sebagai media penyimpanan file yang berformat MP3 dan txt (Mediocto Sahat Adolf dkk, 2015). Modul MP3 dapat diakses dan dikendalikan menggunakan mikrokontroler menggunakan komunikasi SPI (Serial Peripheral Interface) dengan cara mengirimkan intrusksi atau data ke modul MP3. Mikrokontroler akan mengirimkan instruksi atau data menuju ke slave input kartu SD melalui pin serial MOSI.

\section{METODE}

Metode yang digunakan dalam penelitian karya ini adalah AnalysisDesign-Development-ImplementationEvaluation (ADDIE). Muncul pada tahun 1990-an yang dikembangkan oleh Reiser dan Mollenda. Salah satu fungsinya ADDIE yaitu menjadi pedoman dalam membangun perangkat dan infrastruktur program pembuatan alat yang efektif, dinamis dan mendukung kinerja alat itu sendiri. Model pengembangan yang digunakan dalam penelitian ini adalah model ADDIE oleh Robert Maribe Branch. Model pengembangan ini dipilih karena evaluasi dapat dilakukan di setiap tahap pengembangan.

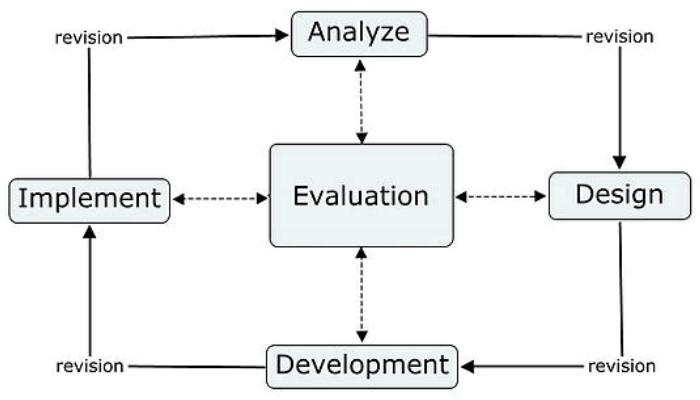

Gambar 3. Kerangka Pengembangan ADDIE (Robert Maribe Branch. 2009;2)
Penulis menggunakan metode ini karena pencerminan kepraktisan rekayasa, yang membuat kualitas sistem tetap terjaga karena pengembangannya yang terstruktur dan terawasi. Di sisi lain model ini merupakan jenis model yang bersifat dokumen lengkap, sehingga proses pemeliharaan dapat dilakukan dengan mudah.

\section{Tahap Analisis dan Studi Literatur}

Analisis merupakan tahap awal yang digunakan sebelum mendesain sebuah alat. Analisis ini digunakan untuk mengklarifikasi apakah ada masalah yang akan dihadapi sehingga nantinya dapat menemukan solusi yang tepat untuk menghadapi masalah dalam penyelenggaraan pembuatan alat. Analisis berupa mencari referensi pemecahan masalah yang timbul dimasyarakat tentang bahaya akibat kurangnya pengetahuan kelistrikan di rumah tangga terutama bagi anak usia dini. Analisis selanjutnya yaitu mengidentifikasikan bahan-bahan yang akan dibutuhkan dalam proses pembuatan modul edukasi.

\section{Desain}

Desain merupakan tahap setelah proses analisis dimana tahap ini adalah tindak lanjut atau kegiatan inti dari langkah analisis. Desain disusun dengan mempelajari masalah, kemudian mencari solusi melalui identifikasi dari tahap analisis kebutuhan pada proses sebelumnya. Dalam pelaksanaan kegiatan ini, penerapan tahap desain dimulai dengan desain blok sistem kerja alat, skematik rangkaian elektronik, desin flowchart alur kerja untuk modul, dan desain alat (casing) modul edukasi keselamatan listrik. 

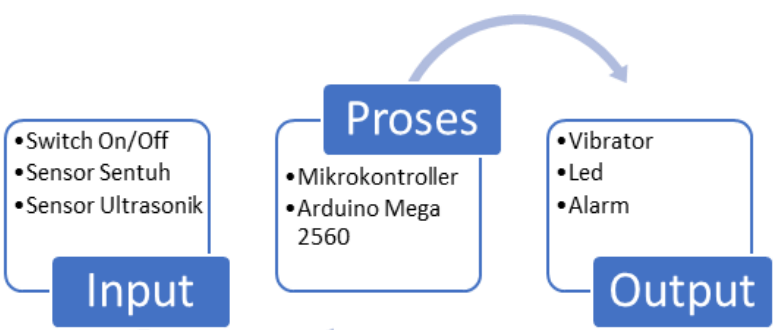

Gambar 4. Desain Blok Alat

\section{Pengembangan}

Tahap pengembangan adalah tahap dimana desain yang sudah tersusun atau sudah terbuat kemudian ditindak lanjuti prosesnya melalui uji coba. Uji coba yang dilakukan meliputi desain blok sistem kerja alat, skematik rangkaian elektronik, desain flowchart alur kinerja firmware untuk hardware, desain pengolahan database, desain prototype atau casing. Apabila dalam tahap uji coba alat yang dibuat terdapat kekurangan maka selanjutnya harus dievaluasi dan dikembangkan untuk kepentingan penyempurnaan.

\section{MULAI}

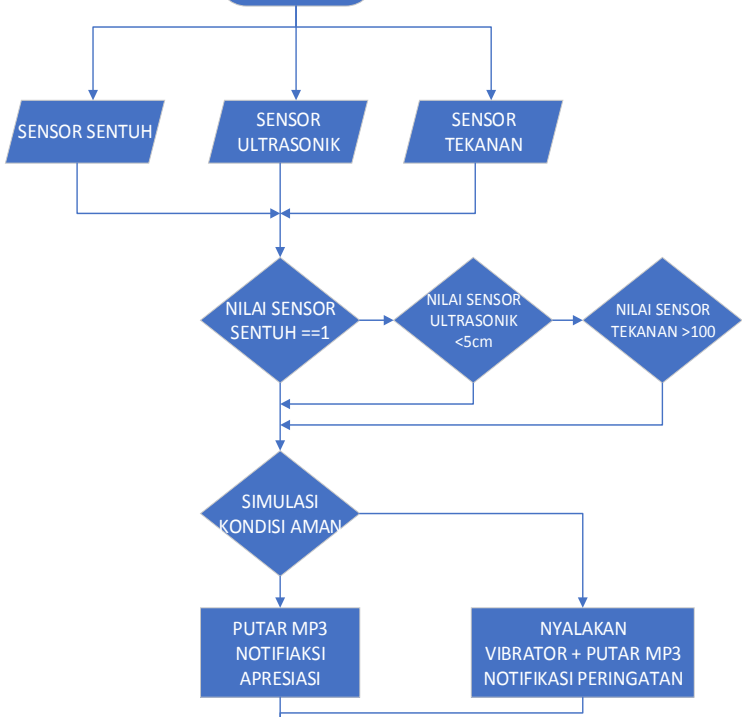

SELESAI

Gambar 5. Diagram Alir Kinerja Alat

\section{Implementasi}

Suatu rencana yang telah dibuat tidak akan kita ketahui hasilnya apabila tidak ada suatu tindakan yang dilakukan. Tahap Implementasi dalam kegiatan ini dilakukan dengan mengabungkan komponenkomponen hardware dan software dari percobaan yang sudah dilakukan untuk dibuat menjadi sistem yang terintegrasi menjadi sebuah prototype.

\section{Evaluasi}

Evaluasi yaitu proses untuk melihat apakah sistem yang sedang dibangun berhasil, sesuai dengan harapan awal atau tidak. Tahap evaluasi bisa terjadi pada setiap empat tahap di atas yaitu pada tahap analisis, desain, pengembangan dan implementasi. Evaluasi yang terjadi pada setiap empat tahap di atas itu dinamakan evaluasi formatif, karena tujuannya untuk kebutuhan revisi untuk menghasilkan sebuah keluaran yang sangat optimal dan baik. Metode pelaksanaan program karsa cipta MOKELIS FOR KIDS secara lebih jelasnya dapat dilihat pada diagram blok sebagai berikut.

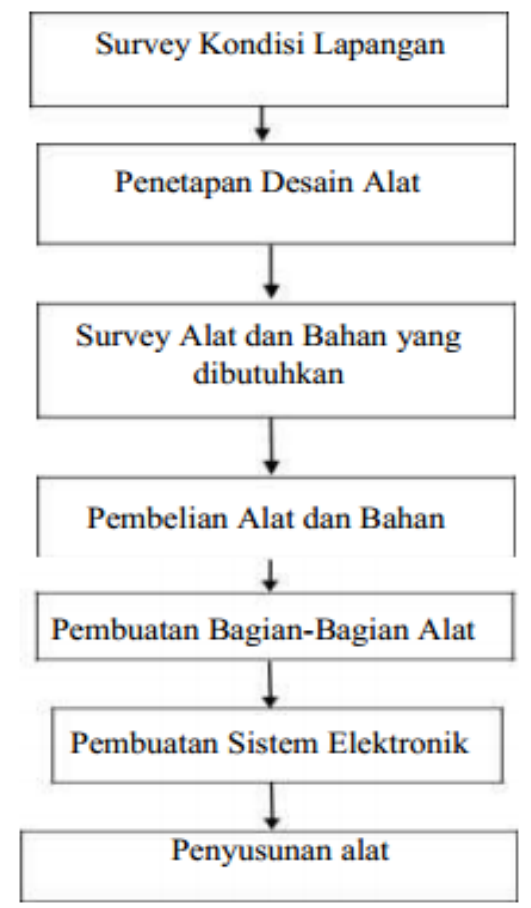

Gambar 6. Diagram Blok Pembuatan MOKELIS FOR KIDS. 


\section{HASIL DAN PEMBAHASAN}

Hasil yang dicapai berupa terciptanya Media Pembelajaran MOKELIS FOR KIDS. Bentuk fisik MOKELIS FOR KIDS dapat dilihat pada gambar berikut:

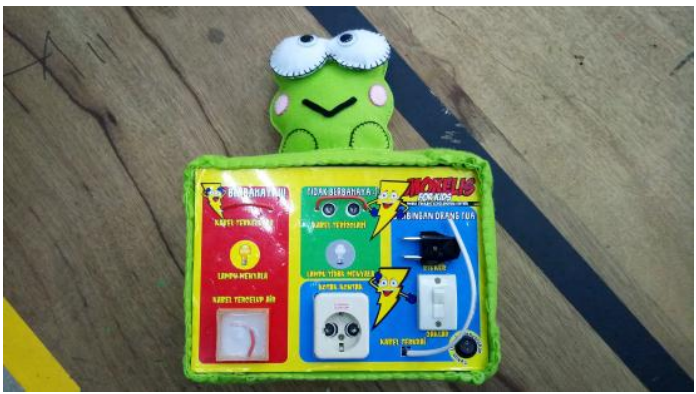

Gambar 7. Bentuk Fisik Media

Pembelajaran MOKELIS FOR KIDS.

Media pembelajaran yang telah dibuat berupa modul edukasi yang terdiri dari Arduino Mega 2560 sebagai kontroler. Input media pembelajaran berasal dari sensor sentuh, sensor ultrasonik, dan push button. Cara kerja media pembelajaran cukup sederhana dan terdiri dari 3 bagian blok. Blok pertama merupakan kondisi berbahaya yang terdiri dari 1 buah sensor sentuh dan 2 buah push button. Ketiga input dari blok kondisi berbahaya akan memberikan output berupa notifikasi suara dan getaran sebagai simulasi kejut listrik. Blok kedua merupakan kondisi tidak berbahaya yang terdiri dari sensor ultrasonik dengan mendeteksi jarak maksimal $6 \mathrm{~cm}$ untuk dapat memutar notifikasi suara. Saat push button ditekan, maka akan notifikasi suara akan diputar. Blok ketiga merupakan blok bimbingan orang tua yang terdiri dari sensor sentuh, sensor ultrasonik, push button, dan saklar, pada blok ini output yang diputar hanya notifikasi suara saja.

Prototype yang telah dibuat telah diujicoba dengan hasil sangat baik. Semua tombol dapat berfungsi dengan baik, sensor ultrasonik dan sensor sentuh dapat berfungsi dengan baik. Modul mp3 dapat memutar notifikasi suara dan motor vibrator dapat berfungsi dengan baik.

Tabel. 1 Unjuk kerja MOKELIS FOR KIDS

\begin{tabular}{llll}
$\begin{array}{l}\text { Nama } \\
\text { Tombol }\end{array}$ & Kinerja & MP3 & $\begin{array}{l}\text { Motor } \\
\text { Getar }\end{array}$ \\
\hline $\begin{array}{l}\text { Saklar } \\
\text { ON/OFF }\end{array}$ & Berfungsi & Berfungsi & - \\
\hline $\begin{array}{l}\text { Kabel } \\
\text { terkelupas }\end{array}$ & Berfungsi & Berfungsi & Berfungsi \\
\hline $\begin{array}{l}\text { Lampu } \\
\text { menyala }\end{array}$ & Berfungsi & Berfungsi & Berfungsi \\
\hline Kabel & & & \\
\hline
\end{tabular}

$\begin{array}{llll}\text { Kabel } & \text { Berfungsi } & \text { Berfungsi } & \text { Berfungsi } \\ \text { Tercelup } & & & \end{array}$

Air

\begin{tabular}{llll}
$\begin{array}{l}\text { Kabel } \\
\text { Terisolasi }\end{array}$ & Berfungsi & Berfungsi & - \\
\hline $\begin{array}{l}\text { Lampu } \\
\text { tidak } \\
\text { menyala }\end{array}$ & Berfungsi & Berfungsi & - \\
\hline Steker & Berfungsi & Berfungsi & - \\
\hline Saklar & Berfungsi & Berfungsi & - \\
\hline $\begin{array}{l}\text { Kabel } \\
\text { Terurai }\end{array}$ & Berfungsi & Berfungsi & - \\
\hline $\begin{array}{l}\text { Kotak } \\
\text { Kontak }\end{array}$ & Berfungsi & Berfungsi & - \\
\hline
\end{tabular}

Tingkat kelayakan MOKELIS FOR KIDS divalidasi oleh 2 orang ahli media yaitu guru TK Al-Furqon, Mrican, Depok, Sleman. Tingkat kelayakan MOKELIS FOR KIDS disajikan pada Tabel 1.

Tabel 1. Tinkat kelayakan MOKELIS FOR KIDS

\begin{tabular}{lllc}
\hline Aspek & $\begin{array}{l}\text { Skor } \\
\text { Rerata }\end{array}$ & Persentasi & $\begin{array}{l}\text { Tingkat } \\
\text { Kelayakan }\end{array}$ \\
\hline Kemanfaatan & 33 & $82,5 \%$ & Layak \\
Kelengkapan & 18,5 & $77,08 \%$ & Layak \\
Kemudahan & 19 & $79,17 \%$ & Layak \\
Total & $\mathbf{7 0 , 5}$ & $\mathbf{8 0 , 1 1 \%}$ & Layak \\
\hline
\end{tabular}




\section{SIMPULAN}

MOKELIS FOR KIDS merupakan modul edukasi listrik berbasis mikrokontroler yang dapat memberikan simulasi kejut listrik menggunakan motor vibrator seperi getar pada handphone dan dapat memutar notifikasi suara pada kondisi bahaya maupun aman.

MOKELIS FOR KIDS telah diujicoba kepada validator dan menghasilkan tingkat kelayakan dari media tersebut mencapai angka $80,11 \%$ sehingga dapat dikategorikan layak.

\section{SARAN}

MOKELIS FOR KIDS menawarkan kemudahan bagi orang tua maupun lembaga pendidikan anak usia dini untuk mengajarkan keselamatan listrik kepada anak usia dini, sehingga diharapkan anak usia dini memahami bagian peralatan listrik rumah tangga mana yang aman disentuh maupun tidak. Penerapan MOKELIS FOR KIDS sebagai media pembelajaran keselamatan listrik diharapkan dapat meningkatkan pemahaman anak usia dini mengenai keselamatan listrik dan dapat mengurangi angka kecelakaan akibat listrik terutama pada anak.

\section{DAFTAR RUJUKAN}

Arifin, J, dkk.(2016). Perancangan Murottal Otomatis Menggunakan Mikrokontroler Arduino Mega 2560. Jurnal Media Infotama. Volume 12. No. 1, Februari 2016:90

Branch, R.M. (2009). Instructional Design: The ADDIE Approach. New York: Springer.
ESFI. (2016). Occupational Injury and Fatality Statistic. https://www.esfi.org/workplace-injuryand-fatality-statistics diakses 14 Oktober 2018

Hernanto, D, dkk. (2014). Pembuatan Gelang Ultrasonik Untuk Alat Bantu Mobilitas Tunanetra Menggunakan Mikrokontroler ATMega8. Jurnal Evolusi. Volume 11 No. 2, September 2014:20

Kementerian Pendidkan dan Kebudayaan. Kamus Besar Bahasa Indonesia. [Online]. Tersedia di https://kbbi.kemdikbud.go.id/entri/listri k. Diakses 15 Oktober 2018

Pratama, H, dkk. (2012). Akuisisi Data Kinerja Sensor Ultrasonik Berbasos Komunikasi Serial Menggunakan Mikrokontroler ATMega32. Jurnal Electrans. Volume 11. No. 2, September 2012:36-43

Setiaji, B, dkk. (2010). Sistem Peringatan Mengginakan Sensor Sentuh Pada Bracket LCD Proyektor Otomatis Berbasis Mikrokontroler AT 89S51. eprints.undip.ac.id

TribunNews.(2018). Bocah 8 Tahun Tewas

Kesetrum Listrik di Lebak Rejo Utara Tambak Sari, Surabaya saat Main Bola.

http://surabaya.tribunnews.com/2018/0 9/05/bocah-8-tahun-tewas-kesetrumlistrik-di-lebak-rejo-utara-tambaksarisurabaya-saat-main-bola, diakses 16 Oktober 2018 